\title{
Editorial
}

Volume 19 Number 2, July 2020

\section{Medical Education during Covid-19 Pandemic - It Is Time to Embrace the New Norm}

The coronavirus disease 2019 (COVID-19) pandemic has affected the socio-economic fabric of the society globally. Educational institutions, including medical schools are no exception. It has caused wide-spread disruption to teaching and learning (T\&L) activities and may impact the future of medical education worldwide. ${ }^{1}$

Primary cause of the disruption is due to the authorities' initiative to flatten the curve of disease transmission by 'locking down' or restricting the movement of people. This is compounded by the teaching hospitals of both the universities and Ministry of Health $(\mathrm{MOH})$ prioritizing their resources to the management of COVID-19 patients, thus limiting access to students training. The COVID-19 pandemic poses health and safety concerns for both, the patients and students, as either group may acquire or spread the virus to another in the course of training. ${ }^{1}$ Academic staff are also at risk from both these groups. In view of these concerns, most medical schools are embracing innovative methods of online teaching and learning to ensure students continue to receive education. ${ }^{2,3}$ This is mainly preclinical content such as basic medical sciences and behavioural sciences. Small groups convene online for virtual session, while clinical skills sessions may also be conducted online. ${ }^{1}$

The innovative technology in medical education is not new. For years, medical schools have been working to minimise didactic lectures in preference for technology-enhanced T\&L methods, promoting self-directed learning, team-based activities and interprofessional education. ${ }^{1}$ While universities globally are transitioning to online teaching formats, it is imperative to ensure equitable accessibility to all students. ${ }^{2}$

Implementation of online medical education faces practical challenges. These include students' and faculty's readiness to embrace online learning, availability of suitable infrastructure and platform, as well as the modality of delivery of content.
The main challenge on the part of the faculty and students is to keep abreast with advances in technology to ensure a seamless experience in online T\&L activities. In a survey on online learning readiness in our campus, only half $(50 \%)$ of academic staff of a medical faculty responded positively. Among the concerns were stability of internet connection, ability to use the technology, limited knowledge and skills in online teaching and the nature of the course that may not be suitable for elearning. ${ }^{4}$ Among the students, more than a half (52\%) were ready to embrace online learning with no issues. The others had concerns in online learning, which include internet connectivity, limited data plan, challenging home learning environment and suitability of the course for online learning. ${ }^{5}$ Overall, for both faculty and students, stability of internet connection and fitting in the medical course for online learning were the major concerns. ${ }^{4,5}$

Conversion from physical face-to-face to online T\&L sessions requires adjustments in term of content delivery. Most classes were being replaced by recorded lectures or live-streams, some of which might not be able to fully replace the values of attending physical classes. ${ }^{6}$ Despite these challenges, many have reported success and have been well received by the students and faculty with high level of satisfaction. ${ }^{3}$

When the overall situation of the pandemic improves, physical face-to-face T\&L sessions may be conducted by strictly adhering to preventive guidelines. Teaching sessions should involve only small group of students and with minimal contact with patients. This undoubtedly will reduce studentpatient contact time and at the same time will increase the burden of the faculty members to provide multiple sessions for smaller groups of students and increased teaching activities.

Another challenge is to ensure appropriate and adequate assessment system in this situation. The 
methods used should be valid, reliable, secure and fair to the students. Theoretical knowledge may be assessed online but clinical assessment may require adjustments. Scenario-based clinical examination ${ }^{7}$ and objectively structured clinical examination (OSCE) using standardised patients may be utilised as alternatives. Nevertheless, some medical schools do conduct examinations online both for clinical and preclinical students using various platforms. ${ }^{2}$ All course learning outcomes should be achieved7 though it is challenging given the current situation and limitation.

The medical schools have an option to cover the components which might not been adequately covered during the peak of the pandemic to a later phase when the situation improves ${ }^{7}$ particularly those components requiring contact with real patients such as eliciting physical signs and performing basic clinical procedures. The options are continually evolving but may include consolidating didactic sessions online earlier to allow for a later clinical encounter, utilising virtual cases, modifying the academic calendar and defer clinical rotations. $^{1}$

While there are many challenges for medical education in the COVID-19 pandemic era, there are opportunities which may change the future direction for the better. Technology-enhanced T\&L activities may be widely embraced that may give a whole new learning experience for the students, both preclinical and clinical. Clinical skills may also be further enhanced with the used of simulated and virtual platforms to replace real patients. This is not only a time to contribute to the advancement of medical education in terms of curricular innovation and transformation, but it may be a seminal moment for many disciplines in medicine. ${ }^{1,2,3}$ Many more opportunities await with the advancement in artificial or augmented intelligence amid the pandemic we face today which will result in more innovations in medical education. It is time to embrace the new norm.

\section{REFERENCES}

1. Rose S. Medical student education in the time of COVID-19. JAMA. 2020; 323(21):2131-2132.

2. Arandjelovic A, Arandjelovic K, Dwyer K, \& Shaw C. COVID-19: Considerations for medical education during a pandemic. MedEdPublish. 2020 May 1. Available from https: / / www.mededpublish.org/manuscripts/3082. Accessed June 19, 2020.

3. Torda AJ, Velan G, \& Perkovic V. The impact of Covid-19 pandemic on medical education. Med $\mathrm{J}$ Aust. 2020. Available from https:// www.mja.com.au/journal/2020/impact-covid-19 -pandemic-medical-education. Accessed June 20, 2020.

4. Mira K. IIUM e-learning readiness survey. 2020. Unpublished data.

5. Marzuki OA \& Samsul D. Readiness for e-learning among medical students of IIUM. 2020. Unpublished data.

6. Ferrel MN \& Ryan JJ. The impact of COVID-19 on medical education. Cureus. 2020;12(3):e7492. Available from https://www.ncbi.nlm.nih.gov/ pmc/articles/PMC7193226/pdf/cureus-001200000007492.pdf. Accessed June 20, 2020.

7. Majlis Perubatan Malaysia. Panduan pengendalian program pendidikan perubatan (ijazah asas) semasa dan pasca Perintah Kawalan Pergerakan COVID-19. 2020 April 6. Available at https: / /mmc.gov.my/wp-content/ uploads/2020/04/MPM-Panduan-PengendalianProgram-Perubatan-COVID-19.pdf. Accessed June 20, 2020.

Assoc. Prof. Dr. Ahmad Marzuki Omar

Prof. Dr. Azmi Md Nor

Kulliyyah of Medicine

International Islamic University Malaysia 